\title{
Fuel Subsidy Corruption and the Illusions of Economic Reconstruction in Nigeria
}

\author{
Akov, Emmanuel Terkimbi \\ Assistant Lecturer, Department of Political science and Public administration, University of Uyo, Uyo, Nigeria \\ Email: akovterry@gmail.com
}

Doi:10.5901/ajis.2015.v4n1p395

\begin{abstract}
The fuel subsidy patchwork in Nigeria has been fraught with elite manipulations and intrigues. This paper analyses the debilitating state of Nigeria's energy-dependent economy against the backdrop of unprecedented oil-generated opulence. The article relies on secondary data. This method enabled the author draw heavily on recorded data thus making for an in-depth analysis. It was found that rampant corruption in the nation's sprawling oil sector is hugely responsible for the intractable economic development slow-motion that has worsened the plight of ordinary Nigerians. While the country's refineries remain moribund, fuel subsidy has, instead created leeway for the criminally-minded elite to squander the commonwealth. Government has demonstrated little or no political will to stem the decay in the oil sector, as underlined by her reluctance to prosecute oil thieves, some of whom are directly or indirectly connected to the apparatus of the state. Unlike in Ghana where government engaged the people and introduced measures to cushion the harsh effects of fuel subsidy phase-out on the poor, in Nigeria, government has often increased the cost of petrol before ever addressing its impacts on vulnerable groups. The paper therefore recommends the revamping of the country's refineries, the strengthening of the fight against corruption and the establishment of a regulatory framework to protect citizens as necessary measures to help improve the poor state of Nigeria's economy and society.
\end{abstract}

Keywords: elite, fuel subsidy, fuel subsidy removal, corruption, economic reconstruction

\section{Introduction}

Discourses on oil are controversial globally. The Nigerian case is not an exception. Whilst crude oil remains a predominant source of energy and wealth for the global economy, its discovery in Nigeria has led to the negation of agriculture, which ab initio employed $75 \%$ of the population and contributed over $80 \%$ to GDP. Today, Nigeria is reliant on oil for about $99 \%$ of its foreign exchange earnings (Aghalino, 2006). She is the world's 14th largest producer of crude oil with the 10th largest proven natural gas reserves. The country has four refineries with an installed produciton capacity of 445,000 barels of fuel per day, adequate enough to meet its domestic needs with a surplus for export (CCPA, 2012).

The above statistics would suggest the formidable potentials of the Nigerian economy. On the contrary however, she remains a large net importer of gasoline and other petroleum products and continues to rank low in human development indicators. Harsh economic realities and frequent world oil price fluctuations prompted the introduction of subsidies in Nigeria's energy sector in the mid 1980s. Something of a creeping phenomenon, the value of the subsidies has gone from 1 Billion in the 1980s to over 6 Billion Dollars in 2011 (CPPA, 2005).

The maintenance of fuel subsidy in Nigeria is said to have led to a situation whereby the commodity became much cheaper in Nigeria (\$0.44 per litre) compared to neighbouring countries like Benin $(\$ 1.04)$, Niger $(\$ 1.07)$, Cameroon (\$1.2) and Chad (\$1.32). Accordingly, it was concluded that large subsidies led to petroleum products smuggling to neighbouring countries and stagnated economic development (Africa's Pulse, 2012). Driven by institutions of global governance - the IMF, World Bank and other Donor agencies, successive Nigerian governments suddenly became determined to phase-out subsidies in consonance with the harsh economic realities of the times (Okogu, 1993).

Over the past decades, the oil subsidy patchwork has been allegedly bedevilled by criminal tendencies of oil importers and sharp practices in the distribution of import allocation, approval of subsidy payments and actual release of subsidy cheques. In Nigeria, more than 25 oil marketers have been indicted to face criminal charges and a host of other marketers that have benefitted from fuel import subsidies are said to be statutorily unqualified to import fuel as they were not licensed to carry out any form of business in Nigeria (Oshunkeye, 2012).

National Assembly investigation into how subsidy has been operated revealed "the crooked manner fuel subsidy has been shared amongst oil marketers and the appalling inefficiency and corruption in the Nigerian National Petroleum Corporation" (Aghedo, 2012:16). Clearly, subsidy has basically benefitted oil cabals, including MNOCs that are not 
interested in building refineries or transforming the poor state of the Nigerian economy.

The succint objective of the paper is therefore to examine the impact of fuel subsidy corruption on Nigeria's economic trajectory. To achieve this, the paper is divided into six basic sections: Section one elucidates on the Conceptual and theoretical perspective, Section two looks at the state and oil in Nigeria, Section three attempts a historicisation of the fuel subsidy framework in Nigeria, Section four considers the case for and against subsidy phase-out in Nigeria, Section five discusses corruption in Nigeria's oil sector, and Section Six neats the work together in the form of conclusions and recommendations.

\section{Conceptual Net}

A subsidy as stipulated by the OECD in a study is basically government action that decreases the consumption price of the consumer and or increases the setting price of the producer (UNEP, 2003). It is any measure that keeps the prices consumers pay for a good or product below market levels for consumers or for producers. A subsidy is a deliberate attempt by the government to support a chosen economic agent - a consumer and a producer and it can be applied in any market that involves the buying and selling of products and or services (CPPA, 2012).

The most featured type of subsidies tends to be agricultural and energy related. Energy subsidies and particularly fuel subsidies have a long history and have been applied in different forms with differing outcomes internationally (Adebiyi, 2011). It is estimated that more than 25 African countries reportedly had one form of energy subsidy or another before 2010-2011, which consumed an average of 1.4 percent of GDP in public resources (Coady, et al., 2010).

Corruption is any action or inaction of any person or group (public or private) deliberately perpetrated to secure advantage for oneself, a relation, associate or group(s) in a manner that detracts from the acceptable regulations, morals and or ethical standards or code thereby constituting a travesty of justice, equity and fair play (Ofoeze, 2004). It is a multifaceted phenomenon that ranges from giving and accepting of bribes to other kinds of fraudulent practices.

It can also be seen as the non-violent criminal and illicit activities committed with the objective of earning wealth illegally either individually or in a group or organized manner, thereby violating existing legislations governing the economic activities of government and its administration. Corruption is endemic almost in every sector in Nigeria and is at the root of poverty and underdevelopment in the country

\section{Theoretical Synergy}

A central premise of the classical elite theory is that in every society, a minority makes the major political and economic decisions. The origins of this theory are traceable to Plato, but its elaboration is in the thoughts of two Italian political sociologists, Vilfredo Pareto and Gaetano Mosca (Chilcote, 1994). At the heart of this theory is a clear presumption of the average citizen's inadequacies. As a consequence, democratic systems supposedly rely on the wisdom, loyalty and acumen of their political leaders, not on the population at large (Walker, 1966).

Based on the theoretical stipulations of elitism, the political system is structured into two groups; the few who lead, that is the elite, and the many who follow, the masses. The elite possess ideological commitments and manipulative skills which makes them suitable for leadership responsibilities, whilst the masses or the "apolitical clay" are a much larger category of passive, inert followers who have both little knowledge and less influence in public affairs. Pareto divides the elite into the governing elite (those who directly or indirectly govern) and non-governing elite (the rest of the elite who are not in government).

The crux of the elite theory, which in a precis, supposes that the game of politics is about elite domination and manipulation epitomizes the scenario in Nigeria's oil sector. More than anything else, oil cartels/cabals in collaboration with the political elite have engaged in a sustained campaign of squandering the commonwealth (Daily Independent, 2006; Okogu, 1993), further, corruption in the oil sector has been linked directly or indirectly to institutions of the state, thereby making it complicit in the rot and decay that pervades the sector.

Government's inability or refusal to probe the apalling corruption in the Nigerian National Petroleum Corporation (NNPC), coupled with its unwillingness to prosecute suspected oil thieves (who undoubtedly, fall within the non-governing elite stratum) is a pointer to the fact that its officials are enmeshed in the wanton corruption in the sector or at least are beneficiaries of it. The fight against corrupt individuals/groups seems to have attenuated in Nigeria in recent years, and government has demonstrated a glaring unwillingness to investigate corruption-related cases especially in the country's sprawling oil sector. The masses who ideally, should be benefactors of the country's oil wealth continue to suffer in pernury and helplessness on account of government's tempered response to corruption, which continues to exacerbate 
the poor state of the country's economy and society.

\section{The State and Oil in Nigeria}

Onuh (1983) describes the oil sector as the most dynamic sector in Nigeria and the development of the oil sector as the most significant event in recent years. Indeed, oil has significantly shaped the nature of the Nigerian state. The various ways in which it has shaped the political economy of the state has been described by Turner (1978) as one involving the compradors and state elites. Jeyifo (2009) alludes to this when he observed that Nigeria's political economy is underpinned by oil, which is the basis of its insertion into the global capitalist system.

It is noteworthy that Nigeria has been described as a rentier state in the literature on politics and development (Akhaine, 2010; Frynas, 1998; Etete, 1995; Khan, 1994). The state collects rents from sales of oil and these are merely distributed through the bureaucratic mill where they are appropriated, missappropriated and siphoned. Local participation in the oil production process is negligible, which explains the dependency on expatriates in the sector and the country's continuing reliance on imports of refined oil into the country, to the detriment of her current account balance.

Political scientists glibly remark that politics is about the state and what it does. This assertion has continued to vindicate itself in both advanced and peripheral socio-economic formations (Akhaine, 2010). Not even the vaunting of globalization with its "roll back" mantra has been able to tame the state. Nowhere else can the politics of oil be understood better than in the state's relations to the oil industry, the oil owning communities and the general citizenry.

Apart from the oil majors with whom it is in patnership, the state allocates oil blocks on the basis of patronage or political considerations (Nwachukwu and Chike; Okogu, 2005), and oil theft, also known as illegal bunkering is perpetrated by persons connected to the apparatus of the state (Daily Independent, 2006). The Ogomudia special security committee referred to them as a "Cartel or Mafia" composed of highly placed and powerful individuals within society. These powerful persons include a few criminally minded former military personnel (Jeyifo, 2009).

Local consumption of refined oil products such as petroleum, kerosene and diesel has been influenced by the imaginary economics known as fuel subsidy (Akhaine, 2010). Often driven by agencies of global governance such as the IMF and the World Bank, it has continued to fuel circles of inflation in an economy in which the informal sector is preponderant. Disagreements over the appropriate derivation formula stalemated the 2005 National Political Conference that sought to address critical national questions plaguing the federation.

The dynamics of oil exploration and exploitation in Nigeria has been undermined by panoply of legal frameworks such as the Petroleum Act of 1969 which vests the entire ownership of all petroleum in the state. The land use decree of 1978 also vests land ownership in the state (Myers, 1991; Mabogunje, 2009). In 2003, the controversial onshore/offshore dichotomy sought to further increase the state's control of oil resources. The 13\% derivation enshrined in the 1999 constitution and the Petroleum Industry Bill (PIB) with promises of a new fiscal regime of transparency and accountability in the oil sector, reduced the incentives for conflict with oil-owning communities.

The importance of oil in Nigeria is such that we can in fact talk about the permeability of oil in ways in which Senator Charles W.Tobey conceived of it in the American context: 'Oil permeates a great deal of our life; it permeates the halls of legislatures; it permeates the congress' (Atiri, 2012:17). Interestingly, in the last few decades, Nigeria has made over US $\$ 500$ billion dollars from oil, but this has not transformed the fortunes of its citizenry, as the earnings are in the hands of a small percentage of the population who have largely embezzled it (Akhaine, 2010). This is perhaps why Lubeck, Watts and Lipschutz (2007) citing Ross opined that:

Nigeria offers an archetypal example of the paradox of oil by which vast oil wealth begets extravagant corruption, deep poverty, polarized income distributions and poor economic performance.

\section{Fuel Subsidy in Nigeria: A Historical Overview}

Petroleum has fed the Nigerian State since production started in commercial quantities in the 1960s. The initial corollary was increased government revenue, robust foreign resources, strong currency and high standard of revenue (Nordhaus, 1973). However, the oil boom experience since the 1960s has led to major increases in oil prices of petroleum products, resulting in huge dependence on oil revenue for basic infrastructural projects in the country. The adoption of a Structural Adjustment Programme (SAP) threw the system of relative prices out of balance. Among the prescriptions of SAP was the phasing out of subsidies, an issue that has remained a bone of contention between the government and multi-lateral lending institutions for several years. This introduced new pressure regarding the question of petroleum products subsidies. 
Until September 30, 1976, there was no increase in pump price of petrol per litre in Nigeria (Ayoade, 2012). In line with SAP prescriptions, the price of petrol was changed on October 1, 1978 from 8.4/5 kobo to 15.30 kobo, an increase of 73.86\% (Elumide, Asaolu and Adereti, 2006). Reasons for the increment included to match galloping inflation, reduce cost of subsidizing fuel, cut cost of governance and reduce epicurean life. On April 20,1982, the pump price was again increased from 15.30 kobo to 20 kobo per litre (Aghedo, 2012).

During the Ibrahim Babangida administration, the price of petrol was increased five times. On March 1, 1986, the price was increased from 20 kobo to 39.5 kobo, representing an 80\% increase. Again on April 10, 1988, government increased the price of petrol per litre from 39.5 kobo to 42 kobo. There was yet another increment on January 1, 1989 when government increased the price from 42 kobo to $42 / 60$ kobo (42 kobo for commercial vehicles and 60 kobo for private vehicles). On December 19, 1989, it was increased to 60 kobo across the board (Ayoade, 2012).In August, 1993, just few days before leaving office IBB's military government announced that the price of petroleum products had been increased to \#7 per litre. This was however reversed by the Interim National Government (ING) as a carrot to gain legitimacy (Okogu, 1993).

It was not long however, before the ING introduced its own price increases with fuel pump price moving from 70 kobo to \#5 per litre. The Abacha administration slashed the price to \#3.25 per litre before increasing the price again to \#15, representing 361.5\% increase on October 2, 1994 (Ayoade, 2012). Due to widespread protests and labour action, the price was reviewed back to \#11 per litre on October 4, 1994.

The fuel pump price of \#11 was retained until December 20,1998, when General Abdulsalami Abubakar hiked the price from \#11 to \#15 per litre. On January 6, 1999, the administration reviewed the price from \#15 to \#20.

During the Civilian administration of President Olusegun Obasanjo, the price of petrol was increased six times. On June 1, 2000, fuel pump price was increased from \#20 to \#30 without consultation with the National Assembly, State Governors and the Nigerian Labour Congress (Aghedo, 2012). Due to agitations against the price increase, it was reviewed from \#30 to \#25 on June 8, 2000. The price of \#25 was however rejected by the organized labour, which led to a further reduction to \#22 on June 13, 2000.

Again, on January ${ }^{\text {st }}, 2002$, a new price of \#26 per litre was introduced. The price was further reviewed upward to \#40 per litre on June 23,2003 . In 2007, the price again skyrocketed to \#70 per litre which was later reviewed downwards to \#65 per litre.

On January 1st, 2012, President Goodluck Jonathan announced that the price of fuel had been increased from \#65 to \#140 per litre, representing about $115 \%$ increase. This New year 'gift' led to the most serious outburst of public disenchantment in Nigeria since 2003 (Barret, 2012).

Table 1: Fuel Pump Price Increases, Nigeria (1966-2012)

\begin{tabular}{|c|c|c|c|}
\hline Date & Price per litre & Regime & $\begin{array}{l}\text { Percentage } \\
\text { Increased }\end{array}$ \\
\hline $\begin{array}{l}\text { Between } 1966 \text { and } \\
\text { September } 30,1976\end{array}$ & 8.4/5 kobo per litre & $\begin{array}{l}\text { Tafawa Balewa Aguiyi Ironsi, Yakubu } \\
\text { Gowon and Murtala Mohammed }\end{array}$ & \\
\hline October 1, 1978 & 15.30 kobo & Olusegun Obasanjo & $73.86 \%$ \\
\hline April 20, 1978 & 20 kobo & Alhaji Shehu Shagari & \\
\hline March 1, 1986 & 39.5 kobo & Gen. Ibrahim Babangida & $80 \%$ \\
\hline April 10, 1988 & 42 kobo & $"$ & \\
\hline Jan. 1, 1989 & $\begin{array}{c}42 \text { kobo for commercial vehicles and } \\
80 \mathrm{k} \text { for private vehicles }\end{array}$ & $"$ & $43.0 \%$ \\
\hline Dec. 19, 1989 & 60 kobo uniform price & $"$ & $43.0 \%$ \\
\hline March 6, 1991 & 70 kobo & $"$ & $16.6 \%$ \\
\hline Nov.8, 1993 & $\# 5.00$ & Chief Ernest Shonekan & $614.0 \%$ \\
\hline Nov. 22, 1993 & $\# 3.25$ & Gen.Sani Abacha & \\
\hline Oct. 2, 1994 & $\# 15.00$ & $"$ & $361.5 \%$ \\
\hline Oct. 4, 1994 & $\# 11.00$ & $"$ & \\
\hline Dec.20, 1998 & $\# 25.00$ & Gen. A. Abubakar & $127.0 \%$ \\
\hline Jan. 6, 1999 & $\# 20.00$ & $"$ & \\
\hline June 1, 2000 & $\# 30.00$ & Chief Olusegun Obasanjo & \\
\hline June 8,2000 & $\# 25.00$ & $"$ & \\
\hline June 13,2000 & $\# 22.00$ & $"$ & \\
\hline Jan. 1, 2002 & $\# 26.00$ & $"$ & $18.2 \%$ \\
\hline
\end{tabular}




\begin{tabular}{|c|c|c|c|}
\hline June 20, 2003 & $\# 40.00$ & $"$ & $53.0 \%$ \\
\hline July 9, 2003 & $\# 34.00$ & $"$ & \\
\hline October 1, 2003 & $\# 38.50$ and \#42 & \\
\hline May 29, 2004 & $\# 49.90$ & $"$ & \\
\hline Jan. 2005 & $\# 50.50$ & $"$ & $0.07 \%$ \\
\hline August 2005 & $\# 70$ & Alhaji Umaru Yar'Adua & $117 \%$ \\
\hline January 2007 & $\# 65$ & Goodluck Jonathan & \\
\hline Jan. 1, 2012 & $\# 140$ & " & \\
\hline January 2012 & $\# 97$ & & \\
\hline
\end{tabular}

Sources: Ayoade (2012), Elumilade, Asaolu and Adereti (2006), Simon and Felix (2012), Atiri (2012).

\section{Fuel Subsidy Experiences in Some Sub-Saharan African States}

A number of developed and developing countries have engaged in fossil fuel subsidy policy reforms. These countries include Argentina, France, Brazil, China, Ghana, Senegal, Canada, France and India (World Bank, 2010). Prior to the year 2011, more than 25 African countries reportedly had one form of energy subsidy or another which consumed an average of 1.4 percent of GDP in Public Resources (Coady, et al., 2010:8). Of the 25 African countries with subsidies, the fiscal cost of subsidies in six of them, primarily oil exporters was at or above 2 percent of GDP in 2011 (Aghedo, 2012). According to the International Institute for Sustainable Development (IISD):

Once in place fossil fuel subsidies are extremely difficult to remove. There is no single observed formula for success, country circumstances and changing global conditions are major contributory factors. However, strategies can be identified that contribute to successful reform and respond to individual country circumstances (IISD, 2008:8).

The IISD (2008) identifies six important reform approaches; research; establishing reform objectives; building a coherent reform strategy; implementation; clear frames of progress and monitoring and evaluation. This logical process is expected to be followed before embarking on subsidy reform.

The experiences of Ghana, Senegal, Angola, Cameroon, Mozambique, Guinea and others differ from Nigeria in terms of level of success/acceptance of fuel subsidy Reforms. In Ghana, attempts at reforming fuel subsidy began in 2001 in a collaborative effort with the IMF, as part of the latter's Poverty Reduction and Growth Facility Programme. In February 2001, the Ghanaian government, in a bid to deregulate the sector, raised fuel prices by 91 percent and also introduced an automatic price setting mechanism by June of the same year (CCPA, 2012).

The intent was to help revamp the State-owned Tema Oil Refinery (TOR) and pay off its mounting debts. The exponential increase in pump price was however unsustainable due to the further increase in international oil prices. Accordingly, the new price mechanism had to be abandoned. The Ghanaian government also made unsuccessful attempts to raise gasoline price in 2002 and 2003. It also set up the National Petroleum Authority (NPA) in 2005 which was charged with the responsibility of administering price.

The Ghanaian case is reckoned as a substantial success because the government took important measures before the eventual removal of subsidy in 2011. This is perhaps why there was no dissent or opposition from the Ghananian people. In Ghana, research was conducted to identify those most likely to be impacted by reform; "a communication strategy was employed to increase popular support; semi-independent and transparent institutions were established to manage fuel pricing; domestic prices were linked with international prices and policies were implemented to reduce impacts on the poor" (IISD, 2010:14).

In Senegal, environmental concerns of deforestation prompted government to discourage the use of charcoal and firewood through the removal of import duties on Liquefied Petroleum Gas (LPG) based cooking equipment in the 1970s. Given the successes recorded, the government decided to directly subsidize LPG in 1988. By 1998 however, the burden of subsidy had become unbearable and on the advice of the IMF, the Senegalese Government planned a five year subsidy removal target running on 20 per cent withdrawal yearly until 2002 (CCPA, 2012).

In 2009, the Senegalese government restated its commitment to removing subsidies which saw the increase in price of hitherto subsidized cylinders. The Senegalese experience showed that LPG subsidies were more beneficial to the rich who consumed more LPG. The government also grappled with the problem of smuggling of subsidized LPG to neighbouring countries. The Senegalese case was also recorded as a relative success. The subsidy programme created strong incentives to switch from charcoal to LPG, which yielded environmental benefits (IISD, 2010). However, UNEP (2003) argues that because palliative measures for the poor were not properly articulated, rural populations could not switch to LPG because they could not afford it. Unlike in Ghana, not much information and awareness-raising campaigns 
were put in place before subsidy phase-out.

In Guinea, measures were also introduced to reduce fossil fuel subsidy (Africa's Pulse, 2012) with relative successes. Like the Senegalese case, the Guinea experience revealed that urban households spend a larger share of their income in energy subsidies than rural households. This logic has led many African states to embark on fuel subsidy removal in the belief that it will not impact greatly on rural livelihoods. Expenditure data from the Africa Region's SurveyBased Harmonization Indicators Programme (SHIP) for seven countries which included Guinea, showed that the mean share of total household direct expenditure on energy varied from around 1.90\% (Ghana) to 4.2\% (Sierra-Leone). Subsidy phase-out in Guinea did not meet with rejection perhaps because the people do not distrust their government.

Mozambique also introduced a number of fuel price hikes in 2011 (10\% in April and 8\% in July), to bring prices to cost-recovery levels by early 2012. The intention was to ensure the unrestricted application of the price setting formula which will allow full pass through from changes in the world oil prices. In Mozambique, as in Senegal and Guinea, these price hikes did not meet with widespread disenchantment or disapproval from the populace.

The Nigerian case however, remains a paradox. The simple fact that there is a great measure of distrust in government by the people makes any policy of subsidy removal hard to sell. While there is no doubt that savings will be made, the issues of contention remain the dismal performance of government over the years, in its duty in the provision of physical and social infrastructure.

\section{The Case for Subsidy Removal in Nigeria}

It is opined that developing countries, by and large, tend to be less energy-efficient than they could be, because of subsidies (Okogu, 1993). Even when rationalized principally on grounds of income distribution, it is noted that subsidies for fuel usually tend to favour the rich more than the poor because the former own more cars and use more fuel (Nwachukwu and Chike, 2011:1). In this wise, the NNPC (1993:3) avers that "the subsidy that would be beneficial would be in health care, mass transit and education".

Hotelling (1931) advocated the need to price fuel in a way that recognises its temporariness since a barrel of oil once lifted is gone forever and is no longer available for lifting at a future date. In this context, there should be a 'user' cost to compensate for the fact that future generations are permanently denied access to the same barrel. A consumption tax or subsidy phase-out could prove useful in making up for this by releasing resources with which to transform the economy. Because oil and fossil fuels have a limited lifespan, they fall into a category known as exhaustible resources. In this vein Akhaine (2010:90) notes that:

As for Nigeria, its proven reserves are estimated at 40 billion barrels. This figure could be augmented by new offshore findings. At the rate of 2.5 million barrels per day, the life index of the oil can be put at about 43 years. This merely brings home the fact that oil is finite and that the well will soon dry up.

The common argument advanced for having subsidy for fuel in Nigeria is that it is endowed with huge oil reserves and thus, making energy cheap could enhance economic growth and protect the populace from needless hardships arising from exhorbitant prices. This is nevertheless untenable, as nothing is passed on to future generations. Accordingly, the best way to ensure continuity and inter-generational equity is to exploit the resource optimally and use proceeds from it to transform the economy so that long after the point of reserve-exhaustion, the society can continue to be self sustaining (Solow, 1986; Hartwick, 1977).

It is ridiculous to expect the nation to invest heavily in oil production only for just recovering the cost of production at the end of the day. According to Soyode (2001:55), "the cost of producing crude is irrelevant in the calculation of fuel subsidy". Further, he describes fuel subsidy as the loss of revenue that should have accrued to the federation account were the crude oil allocated for domestic consumption sold at international market prices, rather than at the price for which it is sold to the NNPC.

It is further argued that the importance of appropriately pricing fuel is underlined by the fact that firstly, it provides arbitrage opportunity for marketers who buy cheaply at home and sell exhorbitantly at the border. Thus, it is generally accepted that rational-energy pricing (avoidance of subsidies) constitutes the most viable long-term options for bringing about efficiency because low domestic prices work against efficiency improvements (Okogu, 1993).

It is also averred that there is a sense in which the existence of subsidy accentuates the activities of smugglers. The Neighbouring countries of Chad and Cameroon have much higher prices than Nigeria, a scenario which has increased smuggling activities across the border with these countries. Moreover, the National Treasury is allegedly denied funds amounting to the level of the implied subsidy, part of which appears in the form of huge profits for smugglers (Akhaine, 2010). 
The classical argument for having a subsidy, relates to the need for accelerated development and to improve income distribution. However, the income distribution argument is faulted on grounds that petroleum subsidies are biased in favour of the urban sector. It is not surprising therefore that it has been concluded that fuel subsidy policy benefits the rich more than the poor (Kosmo, 1989). Accordingly, the diversion of scarce resources from other deserving sectors such as education and health, in the name of fuel subsidy is believed to exacerbate inequality and poverty.

\section{The Case against Subsidy Phase-out}

There is a very sound basis for periodically raising domestic fuel prices in Nigeria. Even the most die-hard skeptics would agree with the logic of such a policy. Nonetheless, there are a number of factors that have been responsible for the resistance of a subsidy phase-out. To begin with, there is a genuine concern that the burden of adjustment will not be borne evenly, and that the middle/lower income groups would bear the most of it. This is illustrated by the assertion of Lamido Sanusi Lamido, Former Governor of the Central Bank of Nigeria (CBN), who stated that he could not remember when last he paid for fuel from his pocket (Saturday Sun, 2012).

Ngozi Okonjo Iweala, Nigeria's Finance Minister and Coordinating Minister of the Economy, was also quoted as saying that fuel pump Price increment will affect only a small fraction of Nigerians because $70 \%$ of Nigerians trek (Saturday Sun, 2012). However, as noted by Barret (2012), the increase in fuel pump price will have a debilitating effect on all Nigerians. Comrade Abdulwaheed Omar, Nigeria's Labour President also said in an interview that any fuel price increase is definitely bound to affect the generality of Nigerians, as the cost of food, transport, and education would skyrocket (Simon and Felix, 2012).

Futhermore, it is held that the idea of subsidy removal is inextricably tied to economic adjustment programmes like SAP, which has brought fundamental changes to the Nigerian economy and society. The idea behind SAP is that scarce natural resources like foreign currency or energy would be allocated more efficiently, so as to increase the overall productive efficiency of the economy. But then, the implementation of SAP which is the prerequisite for Nigeria's integration into the global capitalist system has resulted in the worsening of the development crises in Nigeria (Otoghile and Akov, 2011).

Moreso, while the financial sector has done very well largely because the gap between the official and parallel market exchange rates creates lucrative arbitrage opportunities for them, the real sector of the economy has stagnated or even declined. The continuing decline in the Naira exchange rate is a direct reflection of the gap between the two sectors, and the concomittant growth in money supplies. These relates to fuel subsidy in that domestic prices will continue to be evaluated on the basis of the exchange rate which has become like a moving target (Okogu, 1993). In this sense, the recent price increases already appear low when converted on the basis of the prevailing parallel exchange rate, which appears to deteriorate further. Clearly, the problem of fuel subsidy is inescapably tied to the success or failure of SAP in stabilizing the economy.

In the official rhetoric of the Nigerian government, one of the major reasons for removing subsidy for fuel is to curtail smuggling. Nevertheless, it is opined that the chain of cross-border smuggling, by its very nature, must involve oil marketers, truck drivers, the customs, police, immigration and other security officials. Moreover, oil trucks are large, easily recognizable entities that must pass through trunk roads and move through manned borders in order to pass through. Thus, the fact that smuggling persists is suggestive that smuggling activities have the support of top government functionaries (Nwachukwu and Chike, 2012).

High cost of governance is identified as an important corollary for explaining the blanket opposition against fuel subsidy removal (Oshunkeye, 2012). In the wake of fuel subsidy removal, Nigeria's President Goodluck Ebele Jonathan, announced a $25 \%$ basic salary pay cut for political office holders. He also commissioned 1,600 buses for urban transportation. However, many believe that the reduction in basic salaries of public officials is just symbolic and amounts to little. According to Barret (2012:15):

At a point when costs are bound to rise, to simply slash emoluments of workers no matter whether they are aides to the President or not sends a wrong signal to the populace. It suggests that these appointees have either been enjoying totally disproportionate economic benefits so far, or that they will be immunized against the impending economic hardships by special privileges that will replace their withdrawn financial benefits.

An estimated 17,500 officials constituting only 0.015 percent (less than a quarter of a percent) of Nigeria's estimated 150 million people, reportedly earn more than a quarter of the country's annual national budget (Oshunkeye, 2012). As at 2010, the Revenue Mobilization, Allocation and Fiscal Commission (RMAFC), revealed that 17,474 political office holders were earning \#1.12 trillion yearly and of the \#1.12 trillion, salaries reportedly gulped about 
$\# 94,959,545,401.20$ billion while \#1,031,654,689,033.18 trillion went to allowances annually (Oshunkeye, 2012). Simple arithmetics would show that salaries took less than 10 percent of the allowances; suggesting that despite the cut in basic salaries, the figures as processed by RMAFC would still be staggering.

The above developments have led many commentators and analysists to come to the conclusion that the government is insensitive to the plight of her citizens (Aghedo, 2012); Adegboye, 2012). Under normal circumstances, government is expected to fix the country's refineries, which ideally should be producing optimally, before embarking on any policy of subsidy removal (Martins, 2012). Government's inability or unwillingness to revamp the country's moribund refineries is suggestive that top government functionaries are implicated in the rot and shady deals in the oil sector (Bamisoye and Obiyan, 2006).

Accordingly, fuel subsidy removal has come to symbolize not a quest for efficiency, but all that is bad in government; intrigue, corruption, distrust, profligacy, anti-democracy and so on. Moreover, unlike in Ghana, the Nigerian government failed to put in place measures to cushion the harsh impacts of increased prices for fuel, thus failing to alleviate the sufferings of the majority of the citizenry. It is littled wonder therefore, that there was such a blanket opposition to subsidy removal, not because Nigerians did not see the economic rationale for it, but because they distrust their government, which has over the past years subjected her citizenry to all kinds of sacrifices, which did not as much as improve their living conditions.

\section{Corruption in Nigeria's Oil Sector: An Analysis}

Over the past decades, the fuel subsidy patchwork has been plagued by crimimally ochestrated tendencies of oil marketers and other sharp practices in the distribution of import allocations, approval of subsidy payments and actual release of subsidy cheques. Over 25 oil importers have been penciled down to face criminal investigations for one kind of fuel subsidy infraction or another (Eni, 2012). In 2010 alone, fuel subsidy cost Nigeria \#600 billion and in the first eight months of 2011, it reportedly gulped \#1.426 billion in public funds. The Nigerian National Petroleum Corporation stipulated that every litre of fuel sold in Nigeria was subsidized with about \#77 to ensure compliance with the official pump price of \#65 across the country. This amounted to \#3.655 trillion paid to petroleum importers between 2006 and 2011 (Eni, 2012).

According to Sahara Reporters (2011), Oando oil owned by Wale Tinubu, Conoil owned by Mike Adenuga, African Petroleum owned by Femi Otedola, MRS Oil owned by Aliko Dangote's brother, Sayyu Dantata and integrated oil owned by former Minister of Interior, Captain Emmanuel Iheanacho, are among the powerful players in the petroleum sector that have shared \#3.655 trillion between 2006 and 2011 in the guise of importing refined petroleum products. Senator Magnus Ibe, the then Chairman Senate Committee on Petroleum (Down Stream), disclosed that several companies involved in the down stream sector and construction, shared over \#1.426 trillion between January and August 2011 alone.

Table 2: List of some companies implicated in fuel subsidy infractions

\begin{tabular}{|l|l|l|l|}
\hline S/N & Company & Infraction Description & Amount (\#) \\
\hline 1. & Aluminnur Resources Ltd. & $\begin{array}{l}\text { Subsidy vessels for which mother vessels were no longer operational; No } \\
\text { shipping documents. }\end{array}$ & $1,051,030,434.64$ \\
\hline 2. & Brula Energy Ltd. & $\begin{array}{l}\text { Subsidy payments for which mother vessels were not found in location } \\
\text { claimed at the time of transhipment. }\end{array}$ & $963,796,199.85$ \\
\hline 3. & Caades Oil and Gas Ltd. & No evidence of sales proceeds in banks. & $487,799,826.80$ \\
\hline 4. & Capital Oil and Gas Ltd. & $\begin{array}{l}\text { Subsidy payments for which mother vessels were not found in location } \\
\text { claimed. }\end{array}$ & $8,898,180,238.91$ \\
\hline 5. & Capital Oil Plc & Subsidy payments for which mother vessels were not found. & $1,216,298,517.20$ \\
\hline 6. & Ceoti Ltd & No evidence of sales proceeds in banks. & $1,773,421,842.01$ \\
\hline 7. & Conoil Plc & $\begin{array}{l}\text { Subsidy payments without proof of mother vessels bill of lading or daughter } \\
\text { vessel bill of lading. }\end{array}$ & $2,948,078,077.90$ \\
\hline 8. & Downstream Energy Ltd. & Subsidy payments for which mother vessels were not found. & $1,774,089,040.63$ \\
\hline 9. & Eterna Plc & $\begin{array}{l}\text { No evidence of sales proceeds in banks; no proof of existence of } \\
\text { mother/daughter bill of lading. }\end{array}$ & $2,122,859,123.70$ \\
\hline 10. & Eurafic Oil and Gas Ltd. & Subsidy payments for which mother vessels were not found. & $2,261,859,123.70$ \\
\hline 11. & Heyden Petroleum & Subsidy payments for which mother vessels were not found. & $594,716,089.31$ \\
\hline 12. & Lumen Skies Ltd. & Transactions disclaimed by banks. & $774,787,752.86$ \\
\hline 13. & Majore Investment Ltd. & Subsidy payments without authorized signatures. & $959,813,734.22$ \\
\hline
\end{tabular}




\begin{tabular}{|l|l|l|l|}
\hline 14. & Master Energy Oil and Gas Ltd. & Subsidy payments for which mother vessels were not found. & $2,908,996,291.29$ \\
\hline 15. & Matrix Energy Ltd. & $\begin{array}{l}\text { Subsidy payments for which mother vessels were not found; no shipping } \\
\text { document evidencing payment. }\end{array}$ & $6,233,502,137.15$ \\
\hline 16. & Menol Oil and Gas Ltd. & Subsidy payments for which mother vessels were not found. & $1,691,595,830.87$ \\
\hline 17. & Mob International Services & No evidence of sales proceeds from banks. & $2,137,328,914.10$ \\
\hline 18. & MRS Oil and Gas Plc. & No shipping documents evidencing payment. & $6,086,531,305.33$ \\
\hline 19. & Nasaman Oil Services Ltd. & $\begin{array}{l}\text { Subsidy payments for which vessels were not found; no authorised } \\
\text { signature/evidence of sales proceeds from banks. }\end{array}$ & $3,081,370,678.34$ \\
\hline 20. & Naticel Petroleum Ltd. & No evidence of sales proceeds in banks. & $3,081,370,678.34$ \\
\hline 21. & $\begin{array}{l}\text { Ocean Energy Trading and } \\
\text { Services Ltd. }\end{array}$ & Payments for which vessels were not found. & $1,778,180,051.20$ \\
\hline 22. & Pinnacle Contractor Ltd. & Payments for which vessels were not found. & $2,755,646,744.04$ \\
\hline 23. & Sifax Oil and Gas Company & Payments for which vessels were no longer operational. & $1,033,119,489.60$ \\
\hline 24. & Tonque Oil Services & No evidence of sales proceeds in banks. & $1,575,014,046.51$ \\
\hline 25. & $\begin{array}{l}\text { Top Oil and Gas Development } \\
\text { Company Ltd. }\end{array}$ & $\begin{array}{l}\text { Payments for which vessels were not found; no shipping documents were } \\
\text { signed. }\end{array}$ & $2,360,733,485.43$ \\
\hline
\end{tabular}

Source: The Nation (2012:2).

Besides the companies listed in the table above, numerous other oil companies received over \#1 trillion in fuel subsidy payments (Sahara Reporters, 2011). Given these discoveries, there is a growing consciousness and realization among the articulate citizenry that the corrupt elite have no plan for the future. It is clear therefore that fuel subsidy, basically benefitted rich cabals, including MNOCs that are not interested in building refineries (Aghedo, 2012).

The fuel subsidy scandal opened the pandoras box on profligate practices in the country's troubled oil sector. Lawan Farouk, erstwhile Chairman of the House of Representatives Committee set up to investigate fuel subsidy corruption, was implicated in a $\$ 620,000$ bribery saga. It was alleged that there was a taped conversation between Lawan Farouk and oil magnate, Femi Otedola, in which both parties negotiated the payment of the said bribe money to Farouk. The intent was to doctor the fuel subsidy Report and absolve Otedola's company from any wrongdoing (Oderemi, 2012).it is regrettable that despite glaring evidence of the purported bribery incident, the government is yet to prosecute the suspects and bring them to justice.

Thus, if this quantum of misappropriation and corruption has been committed by marketers, individuals and institutions of government, what is the guarantee that the funds which would become available on account of fuel subsidy removal will be used to develop infrastructure, alleviate poverty, generate employment and provide social services?

These elements (the ruling elite) have been largely responsible for the mind-bogging corruption and low economic ebb that has necessitated the deregulation policy and put development on a stand still.

\section{Conclusions}

This paper has ostensibly alluded to the issue of an appropriate product pricing for fuel in Nigeria. Clearly, the discovery of oil has in a précis, had both positive and negative implications for Nigeria's economy and society. While it is admitted that its discovery has led to marginal improvements in the country's infrastructure, the gains have been negligible when compared to the losses (Yusufu, 2005). Moreover, much of the oil-generated wealth has ended up in the hands of a few individuals (the ruling class), while a substantial chunk has appeared as profits for smugglers. Accordingly, majority of Nigerians continue to wallow in abject poverty in the face of stupendous oil-generated opulence.

The institution of a fuel subsidy regime, with the intent to cushion the effect of high prices for petroleum products on poor and vulnerable groups, has not steadied Nigeria's sinking economic ship. This is largely because of the corrupt activities of the "oil cabal" charged with the importation of fuel. Further, smugglers in collaboration with big oil merchants have illegally smuggled subsidized fuel to neighbouring African countries for sale at international prices, thereby engendering scarcity at home. Oil marketers have together mismanaged over $\$ 6$ billion of Nigeria's oil revenue in the past few years (Okogu, 1993; Aghedo, 2012).

The removal of subsidy, ostensibly to halt the activities of corrupt oil marketers/smugglers and make money available for infrastructural development appears to have worsened the economic conditions of Nigerians, particularly the poor. With the removal of fuel subsidy comes indiscriminate and exponential surge in fuel pump prices, along with increases in the cost of food, rent, and transport and so on. Moreover, unlike in Ghana, imperative measures were not put in place to cushion the harsh effects of fuel subsidy phase-out on poor and vulnerable groups before embarking on 
the policy which has led to resistance and protests.

In Nigeria, increases in fuel pump prices have historically dovetailed with promises for economic reconstruction since the 1970s (Okogu, 1993). However, the sacrifices made hardly ever yield considerable benefits. This development has ruptured the social contract between the people and the government, which has led to the former's distrust for the latter's institutions and programmes.

\section{Recommendations}

There is no gainsaying that the current fuel pricing arrangement (retention of fuel subsidy) is not sustainable from a longterm point of view, given the exhaustible nature of oil and because the sector's infrastructure needs continuous modernization and or expansion. However, it is not practical, or even appropriate to raise domestic prices to world levels because the current average income level in Nigeria cannot sustain such an increase. Thus, the real wages of workers should be reviewed upwards to enable them cope with harsh economic conditions occasioned by increased fuel pump prices.

It is needless to state that corruption and criminality in Nigeria's oil sector are the major causes of poverty and underdevelopment in the country. The inability or refusal of successive governments to stem the activities of the corrupt cabal in the oil sector and prosecute oil thieves has conveyed the impression to the public of a government which is not committed to fighting corruption and addressing the country's infrastructural deficits. It is expedient to re-dedicate and reorganize Nigeria's anti-corruption architecture, so as to make it more proactive in the prosecution of those found culpable of corruption. This would enhance transparency and accountability, and in turn increase people's trust for government and its policies.

Government must as a matter of urgency, fast-track the turn-around maintenance of the country's refineries and encourage the building of new ones. This would address the overdependence on importation of refined petroleum products and protect Nigeria's economy from the volatility of global oil prices. In this regard, government should partner with the major oil companies such as Chevron, Shell Bp, Exxon Mobil, Total and other stakeholders in the sector to build refineries in the country. This would greatly reduce the activities of smugglers and other oil criminals, and thus conserve foreign exchange. The initiation and implementation of power sector reform programmes would go a long way in reducing reliance on petroleum products as principal sources of energy in the country. It is also necessary to put in place an effective regulatory framework to protect citizens from exploitation by petroleum marketers.

\section{References}

Adebiyi, O. (2011). "Fuel Subsidy: The True Story". Retrieved September 14, 2014, from http://234Next.com/CSP/Cps/sites/Next/Home/ 5746467-182/fuelsubsidy.

Africa's Pulse (2012). "Fuel Price Subsidies in Subsaharan Africa". Retrieved June 24, 2014 from http://fuelsubsidy.subsaharanAfrica. Initiative.pdf.

Aghalino, O. A. (2006). "An Appraisal of the Oil Sector Reform". In Saliu, H., Anali, E. and Olawepo, R. (eds). Nigeria's Reform Programme: Issues and Challenges. Ibadan: Vantage Publishers:

Aghedo, I. (2012). The Politics of Economic Reforms: Evidence from the 2012 Fuel Subsidy Removel in Nigeria. Unpublished.

Akhaine, O. S. (2010). "Nigeria: Politics and the End of Oil". Review of African Political Economy, Vol. 37, No. 123, pp. 90-91.

Atiri, O. A. (2012). The Politics of Fuel Subsidy and Economic Reconstruction in some African States: The Case of Nigeria. Unpublished M.Sc Thesis, University of Benin, Benin City, Nigeria.

Ayoade, G. (2012). "Why the Cabal Dared Nigerians". Insider Weekly, January 16, pp. 14-31.

Bamisoye, O. A. and Obiyan, A. S. (2006). "Policy Analysis of Oil Sector in Nigeria". European Journal of Social Sciences, Vol.3, No.1, pg. 62.

Barret, L. (2012). "2012: Failing to look Beneath the Surface". Sunday Sun, January 15, pg. 15.

CCPA (2012) Nigeria: Fuel Subsidy. New York: Adam Smith International.

Chilcote, R. H. (1994) Theories of Comparative Politics: The Search for a Paradign Reconsidered. Boulder: Westview Press.

Coady, C. et al (2010) "Petroleum Subsidies: Costly, Inequitable and Rising". IMF Staff Position Note.

Daily Independent (2006) "Oil and the Nigerian State" May 2, pg. 16.

Elumide, DF. O., Asaolu, T. O. and Adereti, S. A. (2006) "Appraising the Institutional Framework for Poverty Alleviation Programmes in Nigeria". International Research Journal of Finance and Economics. Issue 3, pg. 71.

Eni, H. (2012) "Boom or Bust for Nigeria?" Tell, January 9, Pg. 50.

Etete, D. (1995) "Investment Prospect in the Petroleum Sector". Report on the Second Nigeria Economic Summit. Ibadan: Spectrum Books.

Frynas, G. F.(1998) "Political Instability and Busines: Focus on Shell in Nigeria". Third World Quarterly, Vol. 19, No.3, pp. 457-478. 
Hartwick, J. M. (1977) "Inter-generational Equity and the Investing of Rents from Exhaustible Resources". American Economic Review, $67(5)$.

Hotelling, H. (1931) "The Economics of Exhaustible Resources". Journal of Political Economy, April.

IISD (2010) Strategies for Reforming Fossil Fuel Subsidies: Practical lessons from Ghana, France and Senegal.Geneva: Global Subsidies Initiative.

Jeyifo, B. (2009) "Niger Delta, Our Country Our Continent and the Global Justice Movement". The Constitution, September 1-16.

Khan, S. A. (1994) Nigeria: The Political Economy of Oil. Oxford: Oxford University Press.

Kosmo, M. (1989) "Commercial Energy Subsidies in Developing Countries". Energy Policy, 17(3).

Lubeck, P.M., Watts, M.J., and Lipschutz, R. (2007) "Convergent Interests: US Energy Security and the 'Securing' of Nigerian Democracy". International Policy Report, February 1-23.

Mabogunje, A. L. (2009) "Land Reform in Nigeria: Progress, Problems and Prospects". Accessed August 16th, from http://siteresources. worldbank.org/ExTARD/resources.

Martins, O. (2012) "Dirty Details of Rot at Nigeria's Refineries". Sunday Sun. April 29, pp. 34-35.

Myers, G. W. (1991) Land and Power: The Impact of the Land Use Act in South West Nigeria. Land Tenure Centre: University of Winsconsin-Madison.

Northaus, W. D. (1973) "The Allocation of Energy Resources". Brookings Paper No. 2.

Nwachukwu, M. U. and Chike, H. (2011) "Fuel Subsidy in Nigeria: Fact or Fallacy". Accessed September, 12, 2014 from www.elsevier.com/locate/energy.

Oderemi, K. (2012) "Farouk/Otedola Saga: From the Serious to the Ludicrous". Accessed October 22, 2014 from http://tribune.com.ng/ sat/index.phy/politics.today/7888.

Ofoeze, H. G. (2004) "Corruption in Nigeria: Its Dimension, Effects and the Fight against it". African Journal of Political and Administrative Studies, Vol. 1, No.1.

Okogu, B. (1993) "Issues in Petroleum Product Pricing in Nigeria". Journal of African Economies, Vol. 4, No. 3, pp.378-405.

Okogu, B. (2005) "The Quest for Transparency in the Petroleum Sector: Case Study of Nigeria in the Context of Ongoing Reforms". Paper presented at Workshop on Good Governance, organised by Chatham House at the Royal Academy, London. 21-23 September.

Onuh, J. K. (1983) The Nigerian Oil Economy. New York: St.Martins Press.

Oshunkeye, S. (2012) "At Last, People's Power". Sunday Sun. January 15, pg.71.

Otoghile, A. and Akov, E. T. (2011) "Globalization and African Developoment: The Neo-classical Liberal Perspective Pre-examined". Nigerian Journal of Social and Development Studies, Vol. 8, No.1.

Sahara Reporters (2011) Fuel Subsidy: Senate Releases Named Cabal. Accessed October 13th 2014 from http://saharareporters.com/ news.page.

Simon, O.E. and Felix, U. A. (2012) The Politics of Fuel Subsidy: Populist Resistance and its Socio-economic Implications for Nigeria. Global Journal of Human Social Science.

Solow, R. M. (1986) "On the Inter-generational Allocation of Natural Resources". Scandinavian Journal of Economics, 88(1).

Soyode, G. A. (2001) "Deregulation of the Downstream Sector: Matters Arising". Economic Indicators, 7(2), pp. 35-60.

The Nation (2012) Sunday, August 26, pg. 2.

Turner, T. (1978) "Commercial Capitalism and the 1975 Coup". In Panter-Brick, K. (ed). Soldiers and Oil: The Political Transformation of Nigeria. London: Frank Cass.

UNEP (2003) "Energy Subsidies: Lessons Learned in assessing their impact and designing Policy Reforms". Retrieved July 12, 2014 from www.Unep.ch/eth/publications/energysubsidies/Energy subreport.pdf.

Walker, J. L. (1966) A Critique of the Elitist Theory of Democracy. The American Political Science Review, Vol 60, No. 2, pp.285-295.

World Bank (2010) Subsidies in the Energy Sector: An Overview. New York: The World Bank Group.

Yusufu, A. A. (2005) "Petroleum and Nigerian Foreign Policy: Autonomy or Dependency in Foreign Policy" NAPSS Journal of Politics and International Relations, Vol. 1, Fourth Edition. 
